\title{
Evaluation of the Antidepressant Effect of the Functional Beverage Containing Active Peptides, Menthol and Eleutheroside, and Investigation of Its Mechanism of Action in Mice
}

\author{
Yuanjin Qi ${ }^{1} \odot$, Huizhen \\ Zhang $^{1} \odot$, Sha Liang ${ }^{1} \oplus$, Jiajia \\ Chen $^{2} \odot$, Xiaoni Yan'®, \\ Zhouyu Duan'® ${ }^{\top}$, Deyang \\ Zhou'• and Zhicheng $\mathrm{Li}^{1 *}{ }^{1 *}$
}

${ }^{1}$ College of Food Science and Engineering, Northwest A\&F University, 22 Xinong Road, 712100 Yangling, PR China

2Department of Food Science, University of Tennessee, 2510 River Dr, TN 37996 Knoxville, USA

Received: 11 November 2019 Accepted: 2 September 2020

*Corresponding author:

Phone/Fax: +862987092486 E-mail:957976900@qq.com lizhicheng@nwsuaf.edu.cn

\section{SUMMARY}

Research background. Depression has become a global threat to human health. In order to solve it, researchers have conducted multi-faceted studies including diet. Many food-derived bioactive substances have shown antidepressant effects. However, there are few studies on the design of industrialized food with antidepressant effect. This study aims to evaluate the antidepressant effect of afunctional beverage made from several ingredients with potential antidepressant function and investigate its antidepressant mechanisms.

Experimental approach. The beverage consists of peppermint oil, active peptides derived from bovine milk casein and Acanthopanax senticosus extract (ASE) whose active ingredient is eleutheroside. Different amounts of ASE were evaluated to determine the optimal concentration of eleutheroside in this functional beverage to deliver the best antidepressant effect through extensive behavioral testing, including preliminary acute stress experiments and further chronic unpredictable mild stress test.

Results and conclusions. The results demonstrated that the beverage with $15 \mathrm{mg} / \mathrm{kg}$ of eleutheroside could significantly reduce the mice's immobility time of tail suspension test and forced swimming test, recover mice's sucrose preference and behavior changes in the open field test, improve the contents of dopamine, norepinephrine, 5-hydroxytryptamine and the activity of superoxide dismutase and reduce the content of malondialdehyde in mice's brains, which indicated that the improvement of monoamine neurotransmitter systems and antioxidation was one potential mechanism of antidepressant action.

Novelty and scientific contribution. This study provides a design of antidepressant functional beverage and an efficient way for the prevention and treatment of depression.

Key words: functional beverage, eleutheroside, behavioral testing, antidepressant mechanism, monoamine, antioxidation

\section{INTRODUCTION}

Major depressive disorder (MDD) is a serious mood disorder, which can be caused by a combination of biological, psychological and social distress. Patients suffering from depression often have unstable emotions, with long-lasting symptoms that usually deprive the patient's capabilities for work and logical communication (1). Depression could even lead to suicide. According to the World Health Organization (WHO), 850000 people commit suicide every year due to depression (2). The WHO had predicted that depression would be one of the two top causes of global health disorders and disability (3).

In addition to common nutrients, foods are also sources of bioactive substances that have a potential positive impact on human health (4). Diet may provide considerable benefits for moderate to severe depression and anxiety (5). According to reports, some Chinese herbal medicines and fruits also have certain antidepressant effects (6-8). Mint, the dried aerial part of the Lamiaceae plant Mentha haplocalyx Briq., is cool-natured, with acrid flavour, and it can disperse stagnated liver in the beliefs of traditional Chinese medicine (9). L-menthol is the main active ingredient of the mint, and its content is up to 87 $\%$ in the essential oil of mint (10). It was able to induce an antidepressant-like effect in a 
mouse model of depressive behavior, and this effect might be partially mediated by dopaminergic (DAergic), 5-hydroxytryptaminergic and gamma-aminobutyric acidergic pathways (9). Acanthopanax senticosus Harms (ASH) root bark is also traditionally used to treat high blood pressure and mental disorders in China $(11,12)$. ASH has an anxiolytic effect against not only mild anxiety, but also anxiety due to higher levels of stress, which is related to an increase in hippocampal brain-derived neurotrophic factor signaling (13). Bioactive peptides are small protein fragments derived from enzymatic hydrolysis and gastrointestinal digestion of food proteins, which are beneficial to living beings (14). Among the many protein foods, milk is a major research object (15). Kim et al. (16) have shown that the ingestion of alpha( $\left.\mathrm{S}_{1}\right)$-casein hydrolysate can decrease the stress-related symptoms in females, particularly in intellectual and emotional problems. Guesdon et al. (17) demonstrated that in mice the tryptic bovine alpha $\left(\mathrm{S}_{1}\right)$-casein hydrolysate has protective effect on sleep during exposure to chronic mild stress conditions. In recent years, the demand for foods with additional functional benefits has been increasing (18). However, the design of industrialized food with antidepressant effect has been rarely explored.

In the present study, a beverage (referred as functional beverage below) was designed, which consisted of peppermint oil, active peptides derived from bovine milk casein and Acanthopanax senticosus extract (ASE) whose active ingredient is eleutheroside. In order to fully confirm antidepressant effect of the functional beverage in mice and determine the optimal concentration of eleutheroside in the functional beverage to deliver the best antidepressant effect, we conducted extensive behavioral testing including preliminary acute stress experiments and further chronic unpredictable mild stress (CUMS) test. The potential antidepressant mechanisms were also investigated.

\section{MATERIALS AND METHODS}

\section{Preparation of functional beverage}

We chose bovine milk casein hydrolysates, peppermint oil (Jinxing Spice, Dongtai, Jiangsu, PR China) and Acanthopanax senticosus extract (ASE; Hongda Plant Chemical, Xi'an, Shaanxi, PR China) as the ingredients of functional beverage and their concentration settings referred to some reports and a Chinese national food standard (19-21). The functional beverage was made of peppermint oil $(0.30 \mathrm{~g} / \mathrm{kg})$, bovine milk casein hydrolysates $(690 \mathrm{~g} / \mathrm{kg})$ and ASE $(0.25-2.00 \mathrm{~g} / \mathrm{kg})$, which contained, respectively, $0.10 \mathrm{~g} / \mathrm{kg}$ menthol, $25.05 \mathrm{~g} / \mathrm{kg}$ active peptides and $3.75-30.00 \mathrm{mg} / \mathrm{kg}$ eleutheroside, consisting of equal amounts of eleutheroside $B$ and eleutheroside $E$.

We prepared and determined bovine milk casein hydrolysates in our previous study with the same enzymes and reagents (22). The protein content of bovine milk casein hydrolysates was determined to be $4.06 \%$ (by mass) by Kjeldahl method (23). The trichloroacetic acid precipitation method
(24) was used to measure the peptide mass fraction of the hydrolysates, which was $3.63 \%$ (by mass). The hydroxyl radical-scavenging activity of bovine milk casein hydrolysates was determined to be $50.06 \%$ by using the 2 -deoxy-D-ribose oxidation method (22). The mass fractions of menthol in peppermint oil and eleutheroside in ASE were respectively 33.33 and $1.50 \%$, which were obtained from the guaranteed analysis provided by the manufacturer. In the following text, all mass fractions refer to the mass fraction of eleutheroside in the functional beverage.

\section{Animals}

Male Kunming mice (20-25 g) and fodder were provided by the experimental animal center of Fourth Military Medical University (Xi'an, Shaanxi, PR China). The production license number of experimental animal was SCXK (Shaanxi) 2014-002. The fodder was standard mice pellet feed. The rearing environment was a specified pathogen-free laboratory animal room with the license number of experimental animal SYXK (Shaanxi) 2014-001. All animals were housed under standard conditions of temperature $(22 \pm 2){ }^{\circ} \mathrm{C}$, humidity (55 \pm 4$) \%$ and light (12:12 h light/dark cycle), and free access to food and water. Clomipramine hydrochloride $(\mathrm{CH}$; Weimeng Biotech, Shanghai, PR China) was used in the present study. All animal use procedures were carried out in accordance with the Regulations of Experimental Animal Administration issued by the State Committee of Science and Technology of the People's Republic of China (25), with the approval of the Northwest A\&F University Ethical Committee. All behavioral experiments were performed once.

\section{Preliminary acute stress experiment}

Treatments in acute stress experiment

Acute stress experiment in the present study included forced swimming test (FST) and tail suspension test (TST), which are used widely to measure the pharmacological effects of antidepressant drugs or changes in stress-evoked behavior in mice $(26,27)$. They were carried out in order to determine the preliminary mass fraction with a better antidepressant effect. In each test, fifty experimental mice were randomly divided into 5 groups $(N=10)$. They were fed with normal saline (control group), $40 \mathrm{mg} / \mathrm{kg} \mathrm{CH}$ (CH group), and three functional beverage samples $(7.50,15.00$ and $30.00 \mathrm{mg} /$ $\mathrm{kg}$ of eleutheroside). All animals in each group were fed twice a day with intragastric administration of $0.02 \mathrm{~mL} / \mathrm{g}$ body mass every time for 5 days continuously. The mice were not anesthetized before gavage. Mice that were subjected to TST and FST were sacrificed by cervical dislocation.

\section{Tail suspension test}

The TST was conducted $1 \mathrm{~h}$ after the last intragastric administration on day 5 . Mice were suspended for $6 \mathrm{~min}$ by placing an adhesive tape $1 \mathrm{~cm}$ away from the tip of the tail. Each 
mouse was suspended $50 \mathrm{~cm}$ away from the floor and was acoustically and visually isolated from other animals during the test. The immobility time of each mouse was subsequently recorded. Immobility was defined as when the mouse's four paws and head were all immobile or passively swinging (28).

\section{Forced swimming test}

The FST was conducted $1 \mathrm{~h}$ after the last intragastric administration on day 5 . Each mouse was placed into an 80 -litre polypropylene basin (height $24 \mathrm{~cm}$, diameter $65 \mathrm{~cm}$ ) filled with $50 \mathrm{~L}$ of water at $(25 \pm 1)^{\circ} \mathrm{C}$. The mouse was forced to swim for 6 min and judged to be immobile when it floated in an upright position and made only small movements to keep its head above water. The duration of immobility was recorded during the last 4 min of the 6 -minute testing period (29). The FST for each mouse was conducted individually.

\section{Further chronic unpredictable mild stress test}

Treatments in chronic unpredictable mild stress test

CUMS test was carried out in order to determine the optimal mass fraction of eleutheroside with the best antidepressant effect. Other 60 mice were divided into six groups $(N=10)$ randomly. There were normal control group, model control group, $\mathrm{CH}$ (40 mg/kg) group, and functional beverage (3.75, 7.50 and $15.00 \mathrm{mg} / \mathrm{kg}$ of eleutheroside) groups. Note that the functional beverage mass fractions were adjusted in CUMS test based on the results of the preliminary acute stress experiment. The functional beverage group $(30.00 \mathrm{mg} / \mathrm{kg})$ was removed and new dose group $(3.75 \mathrm{mg} / \mathrm{kg}$ ) was added. Mice in normal control group and model control group were fed with normal saline. All mice were fed once a day by oral gavage at $0.02 \mathrm{~mL} / \mathrm{g}$ body mass for three weeks. The mice were not anesthetized before gavage.

Normal control group was not stimulated. Other mice were subjected to CUMS as described by Kaye et al. (30) with some modifications. Animals were subjected to stress paradigm randomly once a day over a period of three weeks. The order of stressors is shown in Table 1. After three weeks of stress, an open field test and a sucrose preference test were conducted for each mouse.

Table 1. The arrangement of random stress for animals

\begin{tabular}{cccccccc} 
& \multicolumn{7}{c}{$t /$ day } \\
\cline { 2 - 8 } t/week & 1 & 2 & 3 & 4 & 5 & 6 & 7 \\
2 & $\mathrm{~F}$ & $\mathrm{E}$ & $\mathrm{T}$ & $\mathrm{O}$ & $\mathrm{W}$ & $\mathrm{S}$ & $\mathrm{C}$ \\
3 & $\mathrm{~W}$ & $\mathrm{O}$ & $\mathrm{C}$ & $\mathrm{S}$ & $\mathrm{E}$ & $\mathrm{T}$ & $\mathrm{F}$ \\
& $\mathrm{C}$ & $\mathrm{E}$ & $\mathrm{W}$ & $\mathrm{F}$ & $\mathrm{T}$ & $\mathrm{S}$ & $\mathrm{O}$
\end{tabular}

$\mathrm{F}=$ food deprivation for $24 \mathrm{~h}, \mathrm{E}=$ exposure to empty water bottles for $24 \mathrm{~h}, \mathrm{~T}=$ tail pinch $(60 \mathrm{~s}), \mathrm{O}=$ overnight illumination, $\mathrm{W}=$ exposure to wet caging ( $200 \mathrm{~mL}$ of water into the sawdust bedding) for $24 \mathrm{~h}$, $\mathrm{S}=$ cold water swimming for $5 \mathrm{~min}$ at $4{ }^{\circ} \mathrm{C}, \mathrm{C}=$ tilted cage at 45 degrees for $24 \mathrm{~h}$

\section{Open field test}

A $40 \mathrm{~cm}$ high, $80 \mathrm{~cm}$ long and $80 \mathrm{~cm}$ wide case was prepared for this experiment. The case was separated into 25 equal areas $(16 \mathrm{~cm}$ by $16 \mathrm{~cm}$ ) by drawing black lines. Each mouse was placed at the center of the case at the beginning and allowed to move freely in this open field case. Within the 3-minute test, the time that the mouse stays in the center area, the number of times that the mouse moves across lines, the number of standup times and the number of stools were recorded (31).

\section{Sucrose preference test}

Sucrose preference test was employed herein to determine the anhedonia, which is one of the core symptoms of major depression in humans (32). After chronic stress experiment, each mouse was offered two bottles of water (one with water and the other one with water with $29.24 \mathrm{mM}$ sucrose). This experiment began at 4:00 pm after CUMS and ended at 8:00 am of the second day. Water and sucrose intakes were calculated by weighing each bottle. Then, the sucrose preference was calculated according to the following equation:

$w($ sucrose preference $)=$ $m$ (sucrose) $/[m$ (sucrose) $+m$ (water)]

where $m$ (sucrose) is the mass of sucrose water intake in mice and $m$ (water) is the mass of water intake in mice.

Determination of monoamine and antioxidation

Mice after CUMS were sacrificed by cervical dislocation on the ice pack and their brains were isolated and weighed. Brain homogenates were prepared manually from normal saline and mice brain tissues in a ratio of 9:1 (by mass). The supernates were stored in a $-80^{\circ} \mathrm{C}$ environment after centrifugation at $15000 \times g$ and $4^{\circ} \mathrm{C}$ for $10 \mathrm{~min}$ (H1650; Xiangyi Centrifuge Instruments, Changsha, Hunan, PR China). Levels of dopamine (DA), 5-hydroxytryptamine (5-HT) and norepinephrine (NE) were measured by enzyme-linked immunosorbent assay (ELISA) kits (H710, H104, H096; Jiancheng Bioengineering Institute, Nanjing, Jiangsu, PR China) using a microplate reader (Model 680; Bio-Rad Laboratories, Redmond, WA, USA). Superoxide dismutase (SOD) and malondialdehyde (MDA) were determined by WST-1 method and thiobarbituric acid (TBA) colorimetry by kits (A001-3 and A003-1; Jiancheng Bioengineering Institute) using the above-mentioned microplate reader.

\section{Statistical analysis}

All the results are expressed as mean value \pm standard deviation (S.D.). The data were analyzed by one-way ANOVA test and Duncan's test at $p<0.05$ and $p<0.01$ using the IBM SPSS Statistics v. 20.0 software (33).

\section{RESULTS AND DISCUSSION}

\section{Effects of functional beverage on mouse behavior after preliminary acute stress experiment}

The emotional despair is one of the core symptoms of depression and has causal relevance to committing suicide 


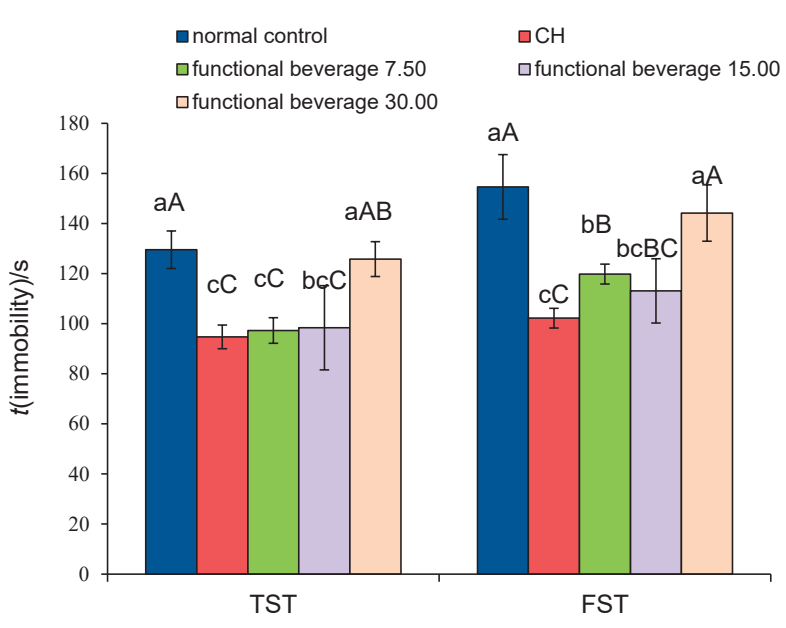

Fig. 1. Effect of functional beverage on the immobility time of tail suspension test (TST) and forced swimming test (FST) in mice. Data are expressed as mean value \pm S.D. $(N=10)$. Different superscripted lowercase letters in the same half region (TST or FST) denote significant differences according to Duncan's test $(p<0.05)$. Different superscripted capital letters in the same half region (TST or FST) denote highly significant differences according to Duncan's test $(p<0.01)$. $\mathrm{CH}=$ clomipramine hydrochloride. Functional beverages $7.50,15.00$ and 30.00 refer to the addition of eleutheroside in $\mathrm{mg} / \mathrm{kg}$

(34). TST is a desperate model induced by the inability to overcome abnormal postures and FST induces despair through the inability to escape the water environment $(35,36)$. In addition, another symptom of depression is psychomotor retardation manifested as the reduction in locomotor activity in rodents, also known as immobility (26). Because the main measures of TST and FST are the reduction of locomotor activity and they contain a desperate environment, they are commonly used as rodent depression models (27).

The effect of functional beverage on the immobility time of TST and FST is shown in Fig. 1. The immobility time in TST and FST was very significantly reduced in the dose groups of 7.50 and $15.00 \mathrm{mg} / \mathrm{kg}(\mathrm{p}<0.01)$ as well as in the positive control $\mathrm{CH}$ group compared to the control group. The dose group of $30.00 \mathrm{mg} / \mathrm{kg}$ had no significant difference ( $p>0.05$ ) from the control group, which suggested that the dose of $30 \mathrm{mg} / \mathrm{kg}$ does not have antidepressant effect. The dose group of 7.50 and $15.00 \mathrm{mg} / \mathrm{kg}$ in TST did not show significant difference
( $p>0.05$ ) from the $\mathrm{CH}$ group, which suggested that these dose groups can reach the same antidepressant effect as $\mathrm{CH}$ group.

These two doses $(7.50$ and $15.00 \mathrm{mg} / \mathrm{kg}$ ) were chosen to be the reference doses for follow-up experiments. Since the highest mass fraction $(30.00 \mathrm{mg} / \mathrm{kg}$ ) did not have antidepressant effect, it was necessary to explore the effect of lower mass fraction in order to obtain the most appropriate mass fractions of eleutheroside. Therefore, the dose group of 3.75 $\mathrm{mg} / \mathrm{kg}$ was added in the follow-up experiments.

\section{Effects of functional beverage in mice after chronic unpredictable mild stress test}

\section{Effects on mouse behavior}

The chronic unpredictable stress model was proposed by Katz et al. (37). The mice suffered a series of different stress stimuli including tail clip, cold-water swimming, and day-night reversal within 21 days, and these stimuli were randomly arranged. After the stimulation, the mice showed a series of emotional behavioral changes, such as reducing horizontal activity and the ability of exploration (38). Lu et al. (39) demonstrated that CUMS-induced depression-like behaviors are coupled with DAergic hyperfunction in the nucleus accumbens and serotonergic hypofunction in the hippocampus and prefrontal cortex.

The results of the open field test and the sucrose preference test are shown in Table 2. All measurements of model group were very significantly different from the control group ( $p<0.01)$, which proved the validity of this chronic mild stress model. The model control group showed significant differences from the $\mathrm{CH}$ group, the dose groups of 7.50 and $15.00 \mathrm{mg} / \mathrm{kg}$ in sucrose preference, the number of the lattice moved, the stand-up times, immobility time, and the number of stool grains $(p<0.05)$, except the dose group of $3.75 \mathrm{mg} / \mathrm{kg}$ in the stand-up times.

Contents of dopamine, norepinephrine and 5-hydroxytryptamine

After accidental finding that monoamine oxidase can inhibit iproniazid, monoamine hypothesis of depression was formulated, which stated that deficiency of monoamine

Table 2. Effect of the functional beverage mass fraction, expressed as eleutheroside, on the open field test and the sucrose preference test in mice

\begin{tabular}{|c|c|c|c|c|c|c|}
\hline Group & $\begin{array}{c}\text { w(eleutheroside)/ } \\
(\mathrm{mg} / \mathrm{kg})\end{array}$ & $\begin{array}{c}w(\text { sucrose } \\
\text { preference)/\% }\end{array}$ & $N$ (lattice moved) & Stand-up time & $t$ (immobility)/s & $N$ (stool grain) \\
\hline Normal control & & $(68.2 \pm 6.2)^{\mathrm{abA}}$ & $(91.0 \pm 5.2)^{\mathrm{bcA}}$ & $(24.7 \pm 3.2)^{\mathrm{abA}}$ & $(13.2 \pm 2.8)^{\mathrm{CCD}}$ & $(1.4 \pm 1.0)^{C B}$ \\
\hline Model control & & $(43.0 \pm 4.4)^{\mathrm{CB}}$ & $(56.7 \pm 3.9)^{e c}$ & $(10.4 \pm 3.2)^{\mathrm{CB}}$ & $(34.9 \pm 8.9)^{\mathrm{aA}}$ & $(396 \pm 1.1)^{\mathrm{aA}}$ \\
\hline $\mathrm{CH}$ & & $(76.0 \pm 12.8)^{\mathrm{aA}}$ & $(98.8 \pm 9.7)^{\mathrm{abA}}$ & $(26.7 \pm 2.8)^{\mathrm{aA}}$ & $(10.8 \pm 3.6)^{C D}$ & $(1.1 \pm 0.7)^{\mathrm{CB}}$ \\
\hline \multirow{3}{*}{$\begin{array}{l}\text { Functional } \\
\text { beverage }\end{array}$} & 3.75 & $(48.5 \pm 8.2)^{\mathrm{CB}}$ & $(69.7 \pm 8.6)^{d B}$ & $(12.6 \pm 2.8)^{\mathrm{CB}}$ & $(22.9 \pm 4.8)^{\mathrm{bB}}$ & $(2.7 \pm 01.0)^{\mathrm{bAB}}$ \\
\hline & 7.50 & $(66.9 \pm 8.9)^{\mathrm{abA}}$ & $(88.0 \pm 7.2)^{c A}$ & $(21.9 \pm 4.4)^{\mathrm{bA}}$ & $(13.3 \pm 4.5)^{\mathrm{CCD}}$ & $(1.3 \pm 1.6)^{\mathrm{CB}}$ \\
\hline & 15.00 & $(71.9 \pm 14.2)^{\mathrm{abA}}$ & $(100.4 \pm 7.9)^{\mathrm{aA}}$ & $(26.1 \pm 6.5)^{\mathrm{abA}}$ & $(11.0 \pm 3.4)^{C D}$ & $(1.1 \pm 0.9)^{\mathrm{CB}}$ \\
\hline
\end{tabular}

Data are expressed as mean value \pm S.D. $(N=10)$. Different superscripted lowercase letters in the same column denote significant differences according to Duncan's test $(p<0.05)$. Different superscripted capital letters in the same column denote highly significant differences according to Duncan's test $(\mathrm{p}<0.01)$. $\mathrm{CH}=$ clomipramine hydrochloride 
Table 3. Effect of the functional beverage mass fraction, expressed as eleutheroside, on the content of dopamine (DA), norepinephrine (NE) and 5-hydroxytryptamine (5-HT) in the brain of mice

\begin{tabular}{|c|c|c|c|c|}
\hline Group & $w($ eleutheroside) $/(\mathrm{mg} / \mathrm{kg})$ & $\gamma(\mathrm{DA}) /(\mathrm{pg} / \mathrm{mL})$ & $\gamma(\mathrm{NE}) /(\mathrm{pg} / \mathrm{mL})$ & $\gamma(5-\mathrm{HT}) /(\mathrm{pg} / \mathrm{mL})$ \\
\hline Normal control & & $(22.3 \pm 2.2)^{\mathrm{abAB}}$ & $(70.5 \pm 8.5)^{\mathrm{bcdBC}}$ & $(95.6 \pm 15.7)^{\mathrm{aA}}$ \\
\hline Model control & & $(16.7 \pm 2.1)^{\mathrm{dc}}$ & $(56.0 \pm 5.1)^{\mathrm{eD}}$ & $(71.4 \pm 2.9)^{\mathrm{cC}}$ \\
\hline $\mathrm{CH}$ & & $(23.1 \pm 2.8)^{\mathrm{aAB}}$ & $(86.1 \pm 9.6)^{\mathrm{aA}}$ & $(98.0 \pm 6.3)^{\mathrm{aA}}$ \\
\hline \multirow{3}{*}{$\begin{array}{l}\text { Functional } \\
\text { beverage }\end{array}$} & 3.75 & $(18.6 \pm 1.8)^{\mathrm{cdBC}}$ & $(62.2 \pm 9.2)^{\mathrm{deCD}}$ & $(80.2 \pm 9.0)^{\mathrm{bcBC}}$ \\
\hline & 7.50 & $(21.5 \pm 2.7)^{\mathrm{abc} A B C}$ & $(73.3 \pm 8.8)^{\mathrm{bc} A B C}$ & $(88.4 \pm 11.4)^{\mathrm{abAB}}$ \\
\hline & 15.00 & $(23.8 \pm 3.9)^{\mathrm{aA}}$ & $(79.2 \pm 11.1)^{\mathrm{abAB}}$ & $(99.0 \pm 10.3)^{\mathrm{aA}}$ \\
\hline
\end{tabular}

Data are expressed as mean value \pm S.D. $(N=10)$. Different superscripted lowercase letters in the same column denote significant differences according to Duncan's test $(\mathrm{p}<0.05)$. Different superscripted capital letters in the same column denote highly significant differences according to Duncan's test $(p<0.01)$. $\mathrm{CH}=$ clomipramine hydrochloride

Table 4. Effect of functional beverage mass fraction, expressed as eleutheroside, on the content of superoxide dismutase (SOD) and malondialdehyde (MDA) in in protein of the mice brain

\begin{tabular}{|c|c|c|c|}
\hline Group & $w($ eleutheroside)/(mg/kg) & Specific activity(SOD)/(U/mg) & $b(\mathrm{MDA}) /(\mathrm{mmol} / \mathrm{g})$ \\
\hline Normal control & & $(402.6 \pm 73.2)^{\mathrm{aA}}$ & $(66.5 \pm 6.2)^{\mathrm{dc}}$ \\
\hline Model control & & $(203.1 \pm 12.7)^{d c}$ & $(157.7 \pm 18.0)^{\mathrm{aA}}$ \\
\hline \multirow[t]{2}{*}{$\mathrm{CH}$} & & $(402.5 \pm 47.2)^{\mathrm{aA}}$ & $(94.4 \pm 11.8)^{\mathrm{bB}}$ \\
\hline & 3.75 & $(277.2 \pm 51.1)^{\mathrm{bcBC}}$ & $(89.7 \pm 17.1)^{\mathrm{bcB}}$ \\
\hline \multirow[t]{2}{*}{ Functional beverage } & 7.50 & $(313.1 \pm 66.3)^{\mathrm{bB}}$ & $(77.8 \pm 10.6)^{\mathrm{cdBC}}$ \\
\hline & 15.00 & $(417.1 \pm 58.7)^{\mathrm{aA}}$ & $(86.5 \pm 10.5)^{\mathrm{bcB}}$ \\
\hline
\end{tabular}

Data were expressed as mean value \pm S.D. $(N=10)$. Different superscripted lowercase letters in the same column denote significant differences according to Duncan's test $(p<0.05)$. Different superscripted capital letters in the same column denote highly significant differences according to Duncan's test $(\mathrm{p}<0.01) . \mathrm{CH}=$ clomipramine hydrochloride

neurotransmitters underlies clinical depression and depressive symptoms can be alleviated by increased monoamine (40-42). Currently, levels of monoamine such as NE, 5-HT and DA are often used as indicators in antidepressant research.

The effect of functional beverage on the contents of DA, $\mathrm{NE}$ and 5-HT in mice's brains is summarized in Table 3. Compared to the normal control group, the contents of DA, NE and 5-HT in mice's brains of the model control group decreased highly significantly $(p<0.01)$, which denoted again that the mouse model of depression was established successfully. The contents of DA, NE and 5-HT of the dose groups of 7.50 and $15.00 \mathrm{mg} / \mathrm{kg}$ significantly increased in comparison with the model group $(p<0.05)$. The dose group of $3.75 \mathrm{mg} / \mathrm{kg}$ did not show significant difference $(p>0.05)$ from the model control group. These results were consistent with the effects on sucrose preference.

Changes of superoxide dismutase activity and malondialdehyde content

Oxidative alterations are recognized as a critical route of brain damage in the pathophysiology of stress-induced psychiatric disorders (43). In stress disorders, oxidative stress triggers or exacerbates several routes of damage such as mitochondrial dysfunction, dysregulation of calcium homeostasis, disruption of energy pathways, damage to neuronal precursors, impairment of neurogenesis and induction of signaling events in apoptotic cell death (44). Oxidative stress is caused by an imbalance between the levels of free radical production and efficiency of the antioxidant enzyme system to neutralize and eliminate reactive oxygen species (ROS). Free-radical damage by ROS, such as the superoxide anion and hydrogen peroxide, is the primary source of oxidative stress (45). Two main antioxidant systems exist. The nonenzymatic system relies on molecules that can directly quench ROS and the enzymatic system is composed of specific enzymes that detoxify ROS. Among the latter, the SOD family is important in oxidative stress modulation (46). In addition, ROS levels are associated with lipid antioxidant defenses. The specific reduction in lipid-targeted antioxidant defenses may contribute to increased ROS levels and oxidative damage to lipid membranes (lipid peroxidation) including to polyunsaturated fatty acids. Lipid hydroperoxide chain reactions eventually cause the formation of reactive aldehydes, the end-product of lipid peroxidation, as indicated by increased levels of MDA (47).

Therefore, SOD activity and MDA content in the brains of mice were measured to reflect oxidative alterations. Whether SOD or MDA, all the functional beverage groups were significantly different compared with the model control group $(p<0.05)$ (Table 4). The dose group of $15.00 \mathrm{mg} / \mathrm{kg}$ has the best effect in increasing SOD activity.

\section{CONCLUSIONS}

In conclusion, the treatment using functional beverage with $15.00 \mathrm{mg} / \mathrm{kg}$ eleutheroside had the best antidepressant 
effect, which significantly reduced the immobility time of mice in the tail suspension test and forced swimming test, and recovered sucrose preference degree. It also significantly improved the content of dopamine, norepinephrine, 5-hydroxytryptamine and the activity of SOD, and decreased the content of MDA in mice's brains, which indicated that the improvement of monoamine neurotransmitter systems and antioxidation was a potential mechanism of antidepressant action. The results implied that the functional beverage made of eleutheroside, active peptides and menthol may be consumed by humans to achieve antidepressant effect.

\section{FUNDING}

This work was supported by the Ministry of Science and Technology (MOST), Government of PR China (No. 2012BAD12B07), and Xi'an Science and Technology Bureau (No. 20193037YF025NS025).

\section{CONFLICT OF INTEREST}

There are no conflicts of interest.

\section{AUTHORS' CONTRIBUTION}

Yuanjin Qi was in charge of design of the work, data collection, data analysis, performing the analysis, drafting the article and critical revision. Huizhen Zhang took part in data collection and data analysis. Sha Liang took part in performing the analysis and drafting the article. Jiajia Chen took part in drafting the article and critical revision. Xiaoni Yan, Zhouyu Duan and Deyang Zhou assisted in data collection. Zhicheng Li was in charge of conception of the design of the work, performing the analysis, drafting the article, critical revision and final approval of the version to be published.

\section{ORCID ID}

Y. Qi @ https://orcid.org/0000-0002-1017-6494

H. Zhang (1) https://orcid.org/0000-0003-0113-2657

S. Liang (1) https://orcid.org/0000-0002-1433-6600

J. Chen (1) https://orcid.org/0000-0002-2068-509X

X. Yan (1) https://orcid.org/0000-0003-3517-7343

Z. Duan (1) https://orcid.org/0000-0001-5397-4712

D. Zhou ๑ https://orcid.org/0000-0003-2640-9202

Z. Li ๑ https://orcid.org/0000-0003-4833-001X

\section{REFERENCES}

1. Ali SS, Khan SA, Khosa F, Aneni EC, Jones A, St Leger AS, et al. Noninvasive assessment of subclinical atherosclerosis in persons with symptoms of depression. Atherosclerosis. 2017;264:92-9.

https://doi.org/10.1016/j.atherosclerosis.2017.07.010

2. Duric V, Banasr M, Licznerski P, Schmidt HD, Stockmeier CA, Simen AA, et al. A negative regulator of MAP kinase causes depressive behavior. Nat Med. 2010;16:1328-32.

https://doi.org/10.1038/nm.2219

3. Chen D, Meng L, Pei F, Zheng Y, Leng J. A review of DNA methylation in depression. J Clin Neurosci. 2017;43:39-46. https://doi.org/10.1016/j.jocn.2017.05.022

4. Admassu H, Gasmalla MAA, Yang RJ, Zhao W. Bioactive peptides derived from seaweed protein and their health benefits: Antihypertensive, antioxidant, and antidiabetic properties. J Food Sci. 2018;83(1):6-16.

https://doi.org/10.1111/1750-3841.14011

5. Null G, Pennesi L. Diet and lifestyle intervention on chronic moderate to severe depression and anxiety and other chronic conditions. Complement Ther Clin Pract. 2017;29:189-93.

https://doi.org/10.1016/j.ctcp.2017.09.007

6. Xiao W, Li S, Wang S, Ho CT. Chemistry and bioactivity of Gardenia jasminoides. J Food Drug Anal. 2017;25(1):43-61. https://doi.org/10.1016/j.jfda.2016.11.005

7. Zhang YJ, Huang W, Huang X, Wang Y, Wang Z, Wang C, et al. Fructus Aurantii induced antidepressant effect via its monoaminergic mechanism and prokinetic action in rat. Phytomedicine. 2012;19(12):1101-7.

https://doi.org/10.1016/j.phymed.2012.05.015

8. Shi MM, Piao JH, Xu XL, Zhu L, Yang L, Lin FL, et al. Chinese medicines with sedative-hypnotic effects and their active components. Sleep Med Rev. 2016;29:108-18.

https://doi.org/10.1016/j.smrv.2015.10.001

9. Wang W, Jiang, Y, Cai E, Li B, Zhao Y, Zhu H, et al. L-menthol exhibits antidepressive-like effects mediated by the modification of 5-HTergic, GABAergic and DAergic systems. Cogn Neurodyn. 2019;13(2):191-200.

https://doi.org/10.1007/s11571-018-9513-1

10. Lin R, Tian J, Huang G, Li T, Li F. Analysis of menthol in three traditional Chinese medicinal herbs and their compound formulation by GC-MS. Biomed Chromatogr. 2002;16(3):229-33.

https://doi.org/10.1002/bmc.131

11. Liao LY, He YF, Li L, Meng H, Dong YM, Yi F, Xiao PG. A preliminary review of studies on adaptogens: Comparison of their bioactivity in TCM with that of ginseng-like herbs used worldwide. Chin Med. 2018;13:57.

https://doi.org/10.1186/s13020-018-0214-9

12. Huang L, Zhao HF, Huang BK, Zheng CJ, Peng W, Qin LP. Acanthopanax senticosus: Review of botany, chemistry and pharmacology. Pharmazie. 2011;66(2):83-97.

https://doi.org/10.1691/ph.2011.0744

13. Miyazaki S, Oikawa H, Takekoshi H, Hoshizaki M, Ogata M, Fujikawa T. Anxiolytic effects of Acanthopanax senticosus HARMS occur via regulation of autonomic function and activate hippocampal BDNF-TrkB signaling. Molecules. 2018;24(1):132.

https://doi.org/10.3390/molecules24010132 
14. Lule VK, Garg S, Pophaly SD, Hitesh, Tomar SK. Potential health benefits of lunasin: A multifaceted soy-derived bioactive peptide. J Food Sci. 2015;80(3):R485-94.

https://doi.org/10.1111/1750-3841.12786

15. Phelan M, Aherne A, FitzGerald RJ, O'Brien NM. Casein-derived bioactive peptides: Biological effects, industrial uses, safety aspects and regulatory status. Int Dairy J. 2009;19(11):643-54. https://doi.org/10.1016/j.idairyj.2009.06.001

16. Kim JH, Desor D, Kim YT, Yoon WJ, Kim KS, Jun JS, et al. Efficacy of $\mathrm{a}_{\mathrm{s} 1}$-casein hydrolysate on stress-related symptoms in women. Eur J Clin Nutr. 2007;61(4):536-41.

https://doi.org/10.1038/sj.ejcn.1602553

17. Guesdon B, Messaoudi M, Lefranc-Millot C, Fromentin G, Tomé D, Even PC. A tryptic hydrolysate from bovine milk $a_{\mathrm{s} 1}$-casein improves sleep in rats subjected to chronic mild stress. Peptides. 2006;27(6):1476-82.

https://doi.org/10.1016/j.peptides.2005.10.001

18. Mikulic-Petkovsek M, Stampar F, Veberic R, Sircelj H. Wild Prunus fruit species as a rich source of bioactive compounds. J Food Sci. 2016;81(8):C1928-37.

https://doi.org/10.1111/1750-3841.13398

19. GB 19301-2010. National food safety standard - Raw milk. Beijing, PR China: Ministry of Health of the People's Republic of China; 2010.

20. Tsai ML, Wu CT, Lin TF, Lin WC, Huang YC, Yang CH. Chemical composition and biological properties of essential oils of two mint species. Trop J Pharm Res. 2013;12(4):577-82. https://doi.org/10.4314/tjpr.v12i4.20

21. Bu Y, Kwon S, Kim YT, Kim MY, Choi H, Kim JG, et al. Neuroprotective effect of HT008-1, a prescription of traditional Korean medicine, on transient focal cerebral ischemia model in rats. Phytother Res. 2010;24(8):1207-12. https://doi.org/10.1002/ptr.2908

22. Li Z, Jiang A, Yue T, Wang J, Wang Y, Su J. Purification and identification of five novel antioxidant peptides from goat milk casein hydrolysates. J Dairy Sci. 2013;96(7):4242-51. https://doi.org/10.3168/jds.2012-6511

23. AOAC Official Method 991.20. Nitrogen (total) in milk, Kjeldahl methods. Rockville, MD, USA: AOAC International; 2006.

24. Almeida CC, Monteiro MLG, da Costa-Lima BRC, Alvares TS, Conte Junior CA. In vitro digestibility of commercial whey protein supplements. LWT - Food Sci Technol. 2015;61(1):7-11. https://doi.org/10.1016/j.lwt.2014.11.038

25. Regulations of experimental animal administration. Beijing, PR China: State Committee of Science and Technology of the People's Republic of China; 2017. Available from: http://www.gov.cn/gongbao/content/2017/content_5219148.htm.

26. Yankelevitch-Yahav R, Franko M, Huly A, Doron R. The forced swim test as a model of depressive-like behavior. J
Vis Exp. 2015;97:e52587.

https://doi.org/10.3791/52587

27. Unal G, Canbeyli R. Psychomotor retardation in depression: A critical measure of the forced swim test. Behav Brain Res. 2019;372:112047.

https://doi.org/10.1016/j.bbr.2019.112047

28. Dhingra D, Bansal Y. Antidepressant-like activity of beta-carotene in unstressed and chronic unpredictable mild stressed mice. J Funct Foods. 2014;7:425-34.

https://doi.org/10.1016/j.jff.2014.01.015

29. Naudon L, El Yacoubi M, Vaugeois JM, Leroux-Nicollet I, Costentin J. A chronic treatment with fluoxetine decreases $5-\mathrm{HT}_{1 \mathrm{~A}}$ receptors labeling in mice selected as a genetic model of helplessness. Brain Res. 2002;936(1-2):68-75. https://doi.org/10.1016/S0006-8993(02)02548-9

30. Kaye J, Morton J, Bowcutt M, Maupin D. Stress, depression, and psychoneuroimmunology. J Neurosci Nurs. 2000;32(2):93-100. https://doi.org/10.1097/01376517-200004000-00005

31. Yang Y, Yang S, Liu J, Feng Y, Qi F, Zhao R. DNA hypomethylation of $G R$ promoters is associated with $G R$ activation and BDNF/AKT/ERK1/2-induced hippocampal neurogenesis in mice derived from folic-acid-supplemented dams. Mol Nutr Food Res. 2019;63(12):e1801334.

https://doi.org/10.1002/mnfr.201801334

32. Ji WW, Li RP, Li M, Wang SY, Zhang X, Niu XX, et al. Antidepressant-like effect of essential oil of Perilla frutescens in a chronic, unpredictable, mild stress-induced depression model mice. Chin J Nat Med. 2014;12(10):753-9. https://doi.org/10.1016/S1875-5364(14)60115-1

33. IBM SPSS Statistics, v. 20.0, IBM Corp, Armonk, NY, USA; 2011. Available from:

https://www.ibm.com/analytics/spss-statistics-software.

34. Xiao WZ, Zhou WH, Ma Q, Cui WG, Mei QY, Zhao X. Serotonergically dependent antidepressant-like activity on behavior and stress axis responsivity of acacetin. Pharmacol Res. 2019;146:104310.

https://doi.org/10.1016/j.phrs.2019.104310

35. Cryan JF, Mombereau C, Vassout, A. The tail suspension test as a model for assessing antidepressant activity: Review of pharmacological and genetic studies in mice. Neurosci Biobehav Rev. 2005;29(4-5):571-625.

https://doi.org/10.1016/j.neubiorev.2005.03.009

36. Petit-Demouliere B, Chenu F, Bourin M. Forced swimming test in mice: A review of antidepressant activity. Psychopharmacology. 2005;177(3):245-55.

https://doi.org/10.1007/s00213-004-2048-7

37. Katz RJ, Roth KA, Carroll BJ. Acute and chronic stress effects on open field activity in the rat: Implications for a model of depression. Neurosci Biobehav Rev. 1981;5(2):247-51. https://doi.org/10.1016/0149-7634(81)90005-1 
38. Willner P. Validity, reliability and utility of the chronic mild stress model of depression: A 10-year review and evaluation. Psychopharmacology. 1997;134(4):319-29.

https://doi.org/10.1007/s002130050456

39. Lu Q, Mouri A, Yang Y, Kunisawa K, Teshigawara T, Hirakawa $M$, et al. Chronic unpredictable mild stress-induced behavioral changes are coupled with dopaminergic hyperfunction and serotonergic hypofunction in mouse models of depression. Behav Brain Res. 2019;372:112053.

https://doi.org/10.1016/j.bbr.2019.112053

40. Naoi M, Maruyama W, Shamoto-Nagai M. Type A monoamine oxidase and serotonin are coordinately involved in depressive disorders: From neurotransmitter imbalance to impaired neurogenesis. J Neural Transm. 2018;125(1):53-66. https://doi.org/10.1007/s00702-017-1709-8

41. Marathe SV, D'almeida PL, Virmani G, Bathini P, Alberi L. Effects of monoamines and antidepressants on astrocyte physiology: Implications for monoamine hypothesis of depression. J Exp Neurosci. 2018;12:1179069518789149. https://doi.org/10.1177/1179069518789149

42. Hirschfeld, RMA. History and evolution of the monoamine hypothesis of depression. J Clin Psychiat. 2000;61(Suppl. 6):4-6.
43. Berk M. Oxidative biology: New intervention opportunities in psychiatry. Acta Neuropsychiatry. 2007;19(4):259-60.

https://doi.org/10.1111/j.1601-5215.2007.00224.x

44. Zafir A, Ara A, Banu N. In vivo antioxidant status: A putative target of antidepressant action. Prog Neuro-Psychopharmacol Biol Psychiatry. 2009;33(2):220-8.

https://doi.org/10.1016/j.pnpbp.2008.11.010

45. Seo MK, Cho HY, Lee CH, Koo KA, Park YK, Lee JG, et al. Antioxidant and proliferative activities of bupleuri radix extract against serum deprivation in SH-SY5Y cells. Psychiat Invest. 2013;10(1):81-8.

https://doi.org/10.4306/pi.2013.10.1.81

46. Bresciani G, da Cruz IBM, González-Gallego J. Manganese superoxide dismutase and oxidative stress modulation. Adv Clin Chem. 2015;68:87-130.

https://doi.org/10.1016/bs.acc.2014.11.001

47. Maes M, Bonifacio KL, Morelli NR, Vargas HO, Barbosa DS, Carvalho AF, Nunes SOV. Major differences in neurooxidative and neuronitrosative stress pathways between major depressive disorder and types I and II bipolar disorder. Mol Neurobiol. 2019;56(1):141-56.

https://doi.org/10.1007/s12035-018-1051-7 